\title{
CANNED BABY FOODS
}

Abou Raya, M. A. ; M. M. M. Tabekha and Dina A. A. Howedy . Food Technology Dept., Fac. of Agric., Mansoura Univ. Egypt .

\section{ABSTRACT}

This investigation summarize the trials to produce canned baby foods from our local vegetables and fruit ( carrot, pumpkin , sweet potato and orange ) suitable for infants from $6-12$ months beside mother feeding .

Twelve's blends from the above vegetables and fruit were mixed with levels $(100,50,25 \%$ ) beside two types of biscuits ( LUX and TIGER ) and ascorbic acid .

The chemical composition of each blends were estimated to show the effect of each content on health during infant growth and its effect on preventing some infant disease.

The obtained data indicated that, the blends from $1-6$ which contains a high value of pumpkin had the highest percentage of protein , vit $A$, vit $C$, phosphor, iron and zinc and also covered the daily requirement of these elements, but it had a deficiency that the protein content was a plant protein . The addition of LUX biscuits and ascorbic acid for blends $7,8,9$ improve the quality and quantity of protein due to skim milk in biscuits and also increase the vit $C$ content $(80.968,86.248,77.963) \mathrm{mg}$ respectively than in control blend. Also the addition of TIGER biscuits (which supported with vitamins and minerals and consist of soy beans ) and orange juice to blends $10,11,12$ increase the value contents of protein and vitamins comparison with control blend. The most of these blends was very useful to prevent some nutrient diseases like caloric deficiency, diarrhea, night blindness ,scurvy, anemia , dwarfism .

The storage of blends in refrigerator during ( 3,6 months ) make a little effect on the total microbial count but there were safety to eat, all blends were free from coliform activity. The addition of biscuits and orange juice improve the organoleptic evaluation. This study was a guide line to establish a new infant food.

Keywords: Carrot, pumpkin , sweet potato , orange juice, biscuits, baby food blends, chemical composition, microbial analysis, sensory evaluation .

\section{INTRODUCTION}

Millions of children in developing counties are suffering from malnutrition as a result of poverty, lack of suitable food, incorrect knowledge in nutrition and superstition. It is during the rapidly growing period of infancy and early childhood that malnutrition is most marked resulting in a high morbidity and mortality.

The formulated weaning food should be able to provide at least $300-$ 400 calories per 100 gram of mixture. It is essential that children be encouraged to consume at least $100 \mathrm{gm}$ of food and that mothers be educated not to cut down quantity of the usual food given to children foods, special attention should be paid to the quality and amount of protein in the product.

Infants are the most vulnerable group who require special attention for their nutritive values particularly at weaning times. After six months of age the quantity of breast feeding milk supplied by the mother is insufficient to meet the energy and nutrient requirements of the growing infant. Consequently, the production of processed foods for infant and children has 
expanded enormously during the last decades. Such foods must not be only nutritious and cheap, but also safe and acceptable to provision of FAO/WHO (1985) committee and the Egyptian Standards for weaning foods (Aly, 1994).

Baby foods are not recommend until the infant is 4 to 6 months old. Cereal grains were the first solid ingredient used in baby food because of their high iron, thiamin and calories content (Wurtman, 1982).

Therefore, the percent study was carried out to prepare high nutritional values canned soft cream infant foods from available locally vegetables rich in carotenoids and to evaluate the chemical nutrition and biological properties of these formulas before and after storage for six month.

So this work was carried out to cover the following topics :-

- Infant and children are practically vulnerable to nutrition deficiency in developing countries and advanced societies.

- Breast feeding by mothers is insufficient to meet the energy and nutrient requirements of growth for infant, so it is important to supply the feeding with processed fruit and vegetables .

- Most our baby foods are import from abroad and cost much money.

- Therefore this work was a trial to produce some blends from local fruits and vegetables as a tradition source for baby foods .

- In this contention the following details were studied:

1-Select some local vegetables ( carrot, pumpkin , sweet potato ) cheap and high in nutrients

2-Designs 12 blends consists of vegetables and fruit and some biscuits with different level contains and determined these blends in chemical composition and microbial analysis

3-Organoleptic evaluation these blends and evaluate these blends about recovering the daily requirements for infants .

On brief this study produce some canned baby food for infant from (612) months rich in vitamins especially in Vit $A$ and Vit $C$ easy and simple prepared for mothers .

\section{MATERIALS AND METHODS}

\section{Materials}

The raw materials which were used throughout the current studies for preparation the different baby food mixtures were :-

A:- fresh vegetables and fruit [Yellow carrots (Daucus carrota) (yc), Pumpkin (Cucurbita pepo) (Pu) ,Yellow sweet potato (Ipomoea batatas lam) (Ysp),Baladi orange (Citrus sincuisis) (Bo)].

All the above mentioned commodities were obtained from the local market at Mansoura market, Dakhlia, Egypt.

B:- Additives [ biscuits No 1(Lux Biscuits) which contain (flour, sucrose, veg. shortening, high fructose or glucose, milk powder, raising agents, food flavours, vanillin- halal) was obtained from Bisco* Miser company, Cairo, Egypt , biscuits No. 2(Tiger Biscuits )which contain(wheat flour, milk ,Soya ,sugar ,palm oil , fructose ,corn starch, raising agent (ammonium hydrogen carbonate , sodium hydrogen carbonate), skimmed milk powder ,whey powder, flavors , vanillin ,salt ,vitamins B1,B2,B5,B6,B12,citric acid) was 
obtained from Eideta company, Cairo, Egypt. and Ascorbic acid pure from EL-Gomhoria company, Cairo, Egypt.

C:- Gerber baby food (control sample) which contain water, carrot, wheat flour, oat flour, potatoes, tomato paste and onion powder. This sample

\section{Methods} was obtained from Gerber Products company.

The following procedures were carried out as a preliminary steps towards preparing baby formulas.

\subsection{Preparation of raw materials :}

Fresh vegetables were thoroughly washed with tap water and peeled with stainless steel peeler. The remaining edible portions of the vegetables were blanched by adding the possible quantity boiling tap water (ratio between vegetables and water was 2:1) for 5-10 minutes.

Orange juice was extracted by a stainless steel screw press. The extracted juice was screened through a single layer of cheese cloth to remove seeds and peels.

The blanched vegetables were mixed together in the following percentage (see Table 3) and blended together in a warning blender for 2 min. For homogeny, after that the baby food mixtures were filled in jars then pasteurizing in autoclave at $121^{\circ} \mathrm{C}$ for $20 \mathrm{~min}$.

Table (1) : The composition of baby foods formulas *:

\begin{tabular}{|c|c|c|c|c|c|}
\hline $\begin{array}{l}\text { Constituents } \\
\text { Blends No. }\end{array}$ & $\begin{array}{c}\text { Carrot } \\
\%\end{array}$ & $\begin{array}{c}\text { Pumpkin } \\
\%\end{array}$ & $\begin{array}{c}\text { Sweet } \\
\text { potato } \\
\%\end{array}$ & $\begin{array}{l}\text { Biscuits } \\
\%\end{array}$ & $\begin{array}{c}\text { Additives } \\
\%\end{array}$ \\
\hline 1 & 100 & --- & --- & --- & --- \\
\hline 2 & --- & 100 & --- & --- & --- \\
\hline 3 & --- & --- & 100 & --- & --- \\
\hline 4 & 25 & 25 & 50 & --- & --- \\
\hline 5 & 25 & 50 & 25 & --- & --- \\
\hline 6 & 50 & 25 & 25 & --- & --- \\
\hline 7 & 25 & 25 & 50 & $10 \%$ Bis No. $1^{* *}$ & $0.1 \%$ Ascorbic acid \\
\hline 8 & 25 & 50 & 25 & $10 \%$ Bis No. $1^{* *}$ & $0.1 \%$ Ascorbic acid \\
\hline 9 & 50 & 25 & 25 & $10 \%$ Bis No. $1^{* *}$ & $0.1 \%$ Ascorbic acid \\
\hline 10 & 25 & 25 & 50 & $10 \%$ Bis No.2*** & $0.1 \%$ orange juice \\
\hline 11 & 25 & 50 & 25 & $10 \%$ Bis No.2*** & $0.1 \%$ orange juice \\
\hline 12 & 50 & 25 & 25 & $10 \%$ Bis No. $2^{* * *}$ & $0.1 \%$ orange juice \\
\hline 13 & & & & $r$ baby food & \\
\hline
\end{tabular}

\subsection{Chemical analysis :}

Moisture, crude protein, lipids, ash and crude fiber content, ascorbic acid , calcium, phosphorus, iron and zinc content were determined according to the method described by A.O.A.C. (2000). Total carbohydrate was calculated by difference .Total calorific value were calculated according to Wilson et al. (1974) and Scleet (1990) .Carotenoids were determined by method described by Wartestein (1957).

\subsection{Microbiological analysis :}

The microbiological tests (total viable bacterial count and coliform bacterial counts) in the stored infant food formulas conducted according to the method described by A.O.A.C (2000). 
Abou Raya, M. A. et al.

\subsection{Organoleptic test :}

Organoleptic evaluation of reconstituted baby food formulas were determined by a taste panel comprised of the staff members according to the system used by Ramadan (1990). The obtained data were statistically analyzed.

\section{5- Statistical analysis :}

Data were subjected to analysis of variance and the least significant difference (LSD) at $5 \%$ probability according to SAS.

\section{RESULTS AND DISCUSSION}

\section{Chemical composition of the raw materials :}

The data presented in Table (2), showed the composition of fresh raw materials used throughout the current study. It could be noticed that the fresh vegetables pumpkin and carrot contained highest percentage of moisture $91.60 \%$ and $87.79 \%$, respectively. While the sweet potato contained the lowest percentage of moisture $75.06 \%$.

These data agreed with Robinson and Decker (1997), they demonstrated that each $100 \mathrm{~g}$ fresh pumpkin fruit pulp contained $92 \mathrm{gm}$ of moisture.

The highest percentage of crude protein was found in pumpkin 12.0 $\%$ followed by carrot $8.501 \%$ and sweet potato $4.543 \%$, respectively.

These results agreed with Robinson and Decker (1997), who said that fresh pumpkin contained $1 \mathrm{gm}$ of crude protein content.

Pumpkin had the lowest value of fat content $1.190 \%$ followed by sweet potato $1.203 \%$ and yellow carrot $1.556 \%$, respectively.

The obtained data were in agree with Manar (1991) who found that the crude fat content of raw carrots were 1.53 on dry weight basis, also Robinson and Decker (1997) demonstrated that pumpkin contained $0.1 \mathrm{gm}$ crude lipid/100 gm fresh weight pulp, also, Gomma (2000) studied the chemical composition of dried pumpkin, and crude lipid content was $0.1 \%$.

From the same table, it might be clear that, the highest crude fiber contents belonged to both pumpkin $13.095 \%$ and carrot $12.785 \%$. While, the lowest fiber value was obtained from sweet potato $5.662 \%$.

These results agreed with EL-Sayed Sahar (2000), she found that the crude fiber content of yellow carrot was $1.10 \%$. On the other hand, Robinson and Decker (1997) demonstrated that fresh pumpkin contained 1.1 $\%$ of crude fiber.

The same table showed the ash content pumpkin seemed to have the highest value $6.226 \%$. Next was carrot $5.242 \%$ and sweet potato 4.759 $\%$.

The highest percentage of total carbohydrate was found in sweet potato $89.495 \%$ followed by carrot 84.701 and pumpkin $84.048 \%$, respectively.

It might be clear that, the sweet potato had the highest value of total calorific due to the high content of carbohydrate, followed by carrot and pumpkin $47.23 \mathrm{k} . c a l$ and $32.008 \mathrm{k} . c a l$, respectively. 
Total carotenoids, vitamin C, calcium, phosphorus, iron and zinc content of raw materials are shown in Table (2). It could be seen that, pumpkin had a highest value of carotenoids $(208.333 \mathrm{mg} / 100 \mathrm{gm})$ and vit. C $(100 \mathrm{mg} / 100$ $\mathrm{gm})$. While, sweet potato had a lowest value of total carotenoids (84.603 $\mathrm{mg} / 100 \mathrm{gm})$, also, carrot had a lowest value of vit. C content $(75.348 \mathrm{mg} / 100$ gm).

Table ( 2 ) The chemical composition of raw materials :

\begin{tabular}{|l|c|c|c|c|c|c|}
\hline \multicolumn{1}{|c|}{$\begin{array}{c}\text { chemical } \\
\text { composition }\end{array}$} & \multicolumn{2}{c|}{ Carrot } & \multicolumn{2}{c|}{$\begin{array}{c}\text { Pumpkin } \\
\text { dwb }\end{array}$} & \multicolumn{2}{c|}{$\begin{array}{c}\text { Sweet potato } \\
\text { wwwb }\end{array}$} \\
\hline Moisture \% & 87.790 & & 91.600 & & 75.060 & \\
\hline Crude Protein\% & 1.038 & 8.501 & 0.016 & 12.100 & 1.133 & 4.543 \\
\hline Crude Fat \% & 0.190 & 1.556 & 0.100 & 1.190 & 0.300 & 1.203 \\
\hline Crude fiber \% & 1.561 & 12.785 & 1.100 & 13.095 & 1.412 & 5.662 \\
\hline Ash \% & 0.640 & 5.242 & 0.523 & 6.226 & 1.187 & 4.759 \\
\hline Carbohydrate \% & 10.342 & 84.701 & 7.060 & 84.048 & 22.22 & 89.495 \\
\hline Total calorific K.cal & 47.230 & ---- & 32.008 & ----- & 96.112 & ----- \\
\hline Total carotenoids Mg /100gm & 28.380 & 241.474 & 28.170 & 335.333 & 32.070 & 128.603 \\
\hline Vitamin CMg/100gm & 9.200 & 75.348 & 8.400 & 100.000 & 20.100 & 80.592 \\
\hline CalciumMg/100gm & 39.300 & 321.867 & 24.800 & 295.238 & 31.200 & 125.100 \\
\hline PhosphorusMg/100 gm & 36.400 & 298.116 & 45.800 & 545.238 & 48.900 & 196.071 \\
\hline IronMg /100gm & 0.310 & 2.539 & 0.830 & 9.881 & 0.640 & 2.566 \\
\hline ZincMg/100gm & 0.250 & 2.048 & 0.330 & 3.929 & 0.310 & 1.243 \\
\hline
\end{tabular}

Concerning the mineral contents, it might be clear that pumpkin had the highest value of iron, phosphorus and zinc 9.881, 545.238 and 3.929 $\mathrm{mg} / 100 \mathrm{gm}$, respectively. While, carrot had the highest value of calcium content $321.867 \mathrm{mg} / 100 \mathrm{gm}$. Also, sweet potato had the lowest value content of calcium, phosphorus and zinc 125.100, 196.071 and $1.243 \mathrm{mg} / 100 \mathrm{gm}$, respectively.

$\mathrm{Ca} / \mathrm{P}$ ratio in carrot was $(1.080), \mathrm{Ca} / \mathrm{P}$ ratio in pumpkin was $(0.541)$ and $\mathrm{Ca} / \mathrm{P}$ ratio in sweet potato $(0.638)$.

1.2. The chemical composition of types of biscuits and orange juice :

The data presented in Table (3), showed the chemical composition of biscuits and orange juice. It could be noticed that the Tiger Biscuit had the highest value of protein and ash content $11.684 \%$ and $1.471 \%$. While, the Lux Biscuit had the highest value of fat and carbohydrate content $19.431 \%$ and $68.22 \%$, respectively.

From the same table, the orange juice had the highest value content of total carotenoids, vit. C, calcium, iron, phosphorus and zinc 16.9, 12.9, $32.0,0.43,47$ and $0.24 \mathrm{mg} / 100 \mathrm{gm}$, respectively.

2-The Chemical composition of 13 blends provided reliable data to explain food insecurity malnutrition and what extended to prevent some nutrient diseases:

From the data presented in table (4) showed that blends no (1) had a high levels of carotenoids $264.75 \mathrm{mg}$ and vit. C , so it recovered the daily requirements of vit $A$ and vit $C$ according to ( FNB 1989). Eating $39.43 \mathrm{gm}$ and $51.059 \mathrm{gm}$ of this blend covered the daily requirements of vit. A and vit. 
Abou Raya, M. A. et al.

$C$ respectively. This blend also had a high content in protein , crude fiber, vitamins and minerals more than control blend .

Table ( 3 ) The chemical composition of biscuits and orange juice :

\begin{tabular}{|l|c|c|c|}
\hline \multicolumn{1}{|c|}{ chemical composition } & Biscuit LUX & Biscuit TIGER & Orange juice \\
\hline Moisture \% & 0.826 & 1.653 & - \\
\hline Crude Protein \% & 9.157 & 11.684 & - \\
\hline Crude Fat \% & 19.431 & 18.174 & - \\
\hline Crude fiber \% & 0 & 0 & - \\
\hline Ash \% & 1.366 & 1.471 & - \\
\hline Carbohydrate\% & 68.22 & 67.018 & - \\
\hline Total carotenoids Mg /100gm & 0.850 & 1.010 & 16.90 \\
\hline Vitamin C Mg /100gm & 1.210 & 0.950 & 12.90 \\
\hline Calcium Mg /100gm & 17.00 & 19.00 & 32.00 \\
\hline Iron Mg /100gm & 0.380 & 0.410 & 0.43 \\
\hline Phosphorus Mg /100gm & 43.00 & 45.00 & 47.00 \\
\hline Zinc Mg /100gm & 0.160 & 0.210 & 0.24 \\
\hline
\end{tabular}

Blend no (2) had a high value content of protein , carotenoids, vit.C and minerals more than control blend . According to the R.D.A eating $91.140 \mathrm{gm}$, $23.566 \mathrm{gm}, 44.660 \mathrm{gm}, 162.204 \mathrm{gm}, 59.074 \mathrm{gm}$ covered $109 \%, 424 \%$, $223 \%, 61.651 \%, 59.074 \%$ of the daily requirements of protein , vit $A$, vit $C$, ca, $p$, fe and zn respectively. Because of that it was very useful to prevent some nutrient diseases ( caloric deficiency, diarrhea, night blindness ,scurvy , anemia , dwarfism ) .

In blend no (3) the protein , vit.C contents were higher than the control blend . Eating $49.404 \mathrm{gm}$ of this blend will covered $202.41 \%$ the RDA of vit. C.

The more percentage of pumpkin to blends increase the protein , carotenoids, vit $c$ and minerals contents . sequentially it covered the RDA of protein and vitamins. But it cold noticed that the protein in blends from no (1) to no (6) was a plant protein , so it had a deficiency of number of essential amino acids which is important for infant growth . It is very important to support this blend with anther amount of protein (animal protein ) like meat ,soybean , milk, dry milk or mushroom .

Also the same table showed that, the addition of LUX biscuits and ascorbic acid pure improve and increase the protein content -due to the dry milk in biscuits - and the content of vit $\mathrm{c}$. So that blends no 7, 8, 9 had a good source to covered the RDA to prevent some nutrient diseases (caloric deficiency, diarrhea, night blindness, scurvy, anemia , dwarfism ) .

Concerning to the blends no $10,11,12$, the addition of TIGER biscuits which supported with soy beans, vitamins and minerals plus orange juice increased the protein, vitamins and minerals comparison with control blend. 
J. Agric. Sci. Mansoura Univ., 32 (3), March, 2007

$\mathrm{T} 4$ 


\section{Microbiological analysis :}

The data presented in table (5) showed the microbial load of baby food blends immediately after sterilization (at zero time ) and after storage for six months at refrigerator $\left(5-10{ }^{\circ} \mathrm{C}\right)$. However the total microbial count was increased with increasing storage period there were safety to eat , All blends were free from coliform activity .

Table (5):The microbial analysis of baby food blends during storage:

\begin{tabular}{|c|c|c|c|c|c|c|}
\hline \multirow{2}{*}{$\begin{array}{c}\text { Storage Time (month ) } \\
\text { Blends No }\end{array}$} & $\mathbf{0}$ & $\mathbf{3}$ & $\mathbf{6}$ & $\mathbf{0}$ & $\mathbf{3}$ & $\mathbf{6}$ \\
\cline { 2 - 6 } & & & & & \\
\hline $\mathbf{1}$ & $0.5 \times 10^{2}$ & $0.8 \times 10^{2}$ & $1.5 \times 10^{2}$ & 0 & 0 & 0 \\
\hline $\mathbf{2}$ & $0.4 \times 10^{2}$ & $0.8 \times 10^{2}$ & $2.4 \times 10^{2}$ & 0 & 0 & 0 \\
\hline $\mathbf{3}$ & $0.4 \times 10^{2}$ & $0.9 \times 10^{2}$ & $3.3 \times 10^{2}$ & 0 & 0 & 0 \\
\hline $\mathbf{4}$ & $0.6 \times 10^{2}$ & $1.7 \times 10^{2}$ & $3.8 \times 10^{2}$ & 0 & 0 & 0 \\
\hline $\mathbf{5}$ & $0.9 \times 10^{2}$ & $3.8 \times 10^{2}$ & $4.3 \times 10^{2}$ & 0 & 0 & 0 \\
\hline $\mathbf{6}$ & $1.3 \times 10^{2}$ & $1.8 \times 10^{2}$ & $4.3 \times 10^{2}$ & 0 & 0 & 0 \\
\hline $\mathbf{7}$ & $1.1 \times 10^{2}$ & $2.8 \times 10^{2}$ & $3.3 \times 10^{2}$ & 0 & 0 & 0 \\
\hline $\mathbf{8}$ & $0.6 \times 10^{2}$ & $3.8 \times 10^{2}$ & $3.9 \times 10^{2}$ & 0 & 0 & 0 \\
\hline $\mathbf{9}$ & $0.9 \times 10^{2}$ & $2.5 \times 10^{2}$ & $3.2 \times 10^{2}$ & 0 & 0 & 0 \\
\hline $\mathbf{1 0}$ & $1.5 \times 10^{2}$ & $2.3 \times 10^{2}$ & $3.6 \times 10^{2}$ & 0 & 0 & 0 \\
\hline $\mathbf{1 1}$ & $1.8 \times 10^{2}$ & $2.2 \times 10^{2}$ & $5.1 \times 10^{2}$ & 0 & 0 & 0 \\
\hline $\mathbf{1 2}$ & $1.2 \times 10^{2}$ & $3.2 \times 10^{2}$ & $5.7 \times 10^{2}$ & 0 & 0 & 0 \\
\hline
\end{tabular}

* T.V.B.C. $=$ Total viable bacterial counts.$($ cells $/$ gm $)$

** C.B.C. = Coliform bacterial counts

\section{Organoleptic test :}

Table (6) showed that the organoleptic evaluation of baby food blends . The mean scores for color, taste ,odor, viscosity and over all acceptability ranged as $10.60-16.30,12.40-28.70,9.10-17.10,11.70-16.60$ and $57.40-88.90$ respectively. So that the addition of biscuits and orange juice improve the scores of banal tests .

Table (6): Organoleptic evaluation of the reconstituted baby food blends

\begin{tabular}{|c|c|c|c|c|c|}
\hline Blends No & color & taste & odor & viscosity & $\begin{array}{c}\text { Over all } \\
\text { acceptability }\end{array}$ \\
\hline $\mathbf{1}$ & 14.20 & 17.40 & 14.10 & 13.20 & 69.50 \\
\hline $\mathbf{2}$ & 10.60 & 12.40 & 9.10 & 11.70 & 57.40 \\
\hline $\mathbf{3}$ & 12.30 & 28.70 & 15.30 & 15.60 & 82.60 \\
\hline $\mathbf{4}$ & 11.50 & 20.90 & 13.50 & 12.30 & 74.30 \\
\hline $\mathbf{5}$ & 12.0 & 17.10 & 11.60 & 12.40 & 68.40 \\
\hline $\mathbf{6}$ & 13.52 & 19.98 & 12.94 & 12.60 & 73.40 \\
\hline $\mathbf{7}$ & 12.26 & 25.20 & 15.90 & 16.60 & 86.40 \\
\hline $\mathbf{8}$ & 13.0 & 21.30 & 14.00 & 15.60 & 81.10 \\
\hline $\mathbf{9}$ & 12.0 & 22.50 & 14.24 & 16.20 & 84.80 \\
\hline $\mathbf{1 0}$ & 16.30 & 27.20 & 17.10 & 15.80 & 88.90 \\
\hline $\mathbf{1 1}$ & 15.0 & 24.30 & 15.10 & 15.0 & 81.20 \\
\hline $\mathbf{1 2}$ & 16.20 & 26.0 & 15.70 & 15.60 & 84.60 \\
\hline $\mathbf{1 3 ( c o n t r o l )}$ & 13.80 & 13.60 & 12.70 & 12.90 & 63.30 \\
\hline Sin & $\mathrm{Ns}$ & $* \star$ & $\mathrm{Ns}$ & $\mathrm{Ns}$ & \\
\hline Lsd & 11.433 & 2.475 & 7.913 & 2.458 & 7.407 \\
\hline
\end{tabular}

All values are means of ten replicates \pm SD.

Sin (significant) Ns= insignificant different ${ }^{* \star}=$ significant

Lsd ( Least significant difference). 
Also, table (6) summarized the statically analysis of average scores for each evaluation organoleptic test . from these data it cold be observed that , there were no significant different in between blends in there color, odor and viscosity . however, with respect to the taste and over all acceptability, the statistical analysis revealed that there was a high significant difference samples .

\section{REFERENCES}

A.O.A.C. (2000) .Official Method of Analysis . Association of Official Analytical Chemists $15^{\text {th }}$ ed., K. Helrich (ED). Arlington .

Aly, A.M.(1994).Chemical , microbiological evaluation of some imported and local baby foods in Egypt. M.Sc. Thesis ,Fd .Sci. and Tech . Dept., Fac. of Agric., Cairo Univ., Egypt .

El - Sayed Sahar ( 2000 ). Technological and biological studies on carrot and sweet potato .Doctor of philosophy . Dept. of Food tech. Fac. of Agric. Cairo Univ.

FAO/WHO (1985). Energy and protein requirement, Report of joint FAO/WHO/UNU Expert consultation. WHO tech. Rep. Ser. No. 724,WHO, Genera.

(FNB)Food and Natrition Board (1989). Recommended dietary allowances, 10th Ed., National Research Council, Washington, Dc, National Academy Press.

Gomma, N. M. (2000). Chemical and technological studies on some infants food formulas. M. Sc. Thesis, Fac. of Agric., Kafr El- Shiekh, Tanta Univ.

Manar(1991) .Effect of processing on quality and nutritive value of some weaning foods. M.Sc. thesis . Dept. of Food tech. Fac. of Agric. Cairo Univ.

Ramadan, B. R. (1990). Chemical and technological studies on some new valley dates. M. SC. Thesis, Fd. Sci. Tech. Dept., Fac. of Agric., Assiut Univ., Egypt.

Robinson, R. W. and Decker - Walters, D. S. (1997)."Cucurbits", CAB International, New York.

Scleet ,EL (1990). Preparation and evaluation of some Infant Foods .M.sc Thesis .Dept. of food sci. Fac. of Agric., Cairo University ,Egypt.

Wartestein, D. V. (1957). Chlorophyll- lelale and Der Supmkroskopische Formwecksec Der plastiden. Experimental Cell Research, 12: 427.

Wilson, E.D.,Fisher, H. and Fagna ,E. (1974) .Principles of Nut. Third ed John, Wiley and Sons Ine. New York . London Sydney .

Wurtman,J.(1982) . New views on feeding babies .Harvared. Medical .school - Health-Leher ( USA)., 7(10) P.3 - 4 . 
Abou Raya, M. A. et al.

أغذية الاطفال المعلبة

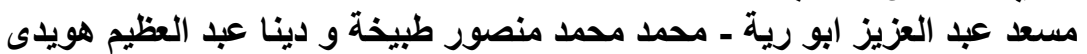

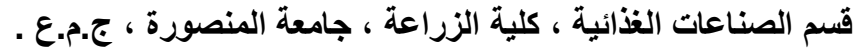

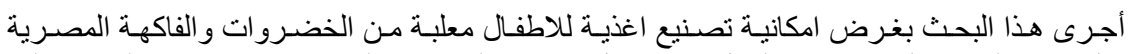

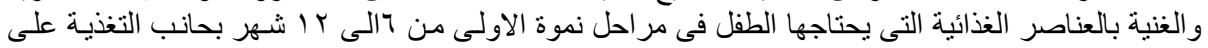

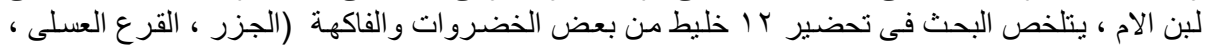

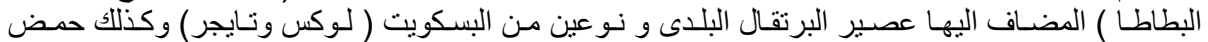

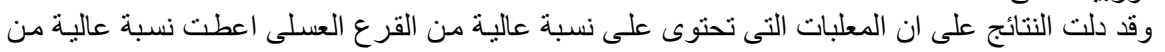

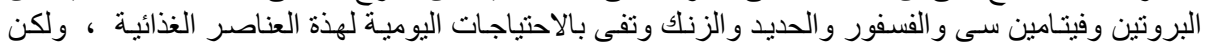

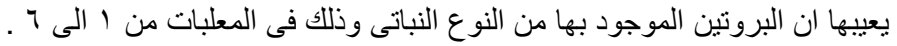

وباضافة بسكويت لوكس وحمض الاسكور ريبك الى المعلبات (

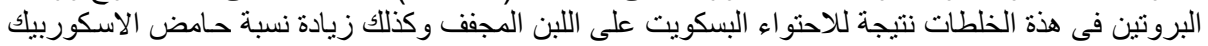

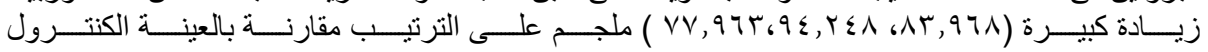
( جربر = (

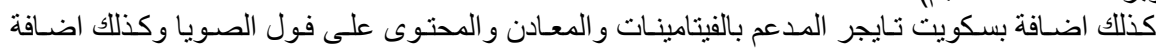

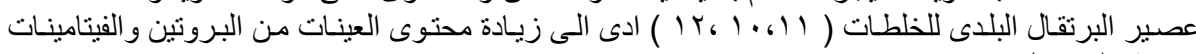

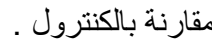

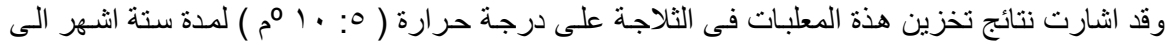

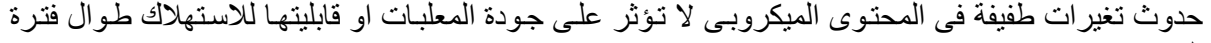

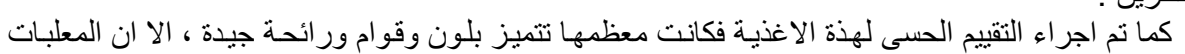
المضاف اليها البسكويت او البسكويت و عصير البرتقال اعطت افضل نتائج فى الطعم والقابلية الكلية . 
J. Agric. Sci. Mansoura Univ., 32 (3), March, 2007 
Table ( 4) :The Chemical composition of 13 blends provided reliable data to explain food insecurity malnutrition and what extended to prevent some nutrient diseases:

\begin{tabular}{|c|c|c|}
\hline Blends No & Chemical composition ( on dry weight bases ) & $\begin{array}{l}\text { explain food insecurity } \\
\text { malnutrition to prevent some } \\
\text { nutrient diseases }\end{array}$ \\
\hline 1 & 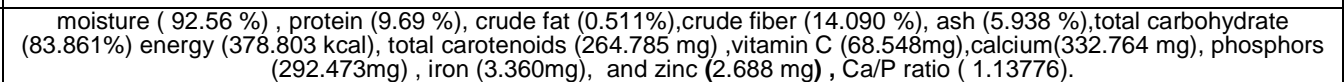 & $\begin{array}{c}\text { caloric deficiency, night blindness, } \\
\text { scurvy }\end{array}$ \\
\hline 2 & 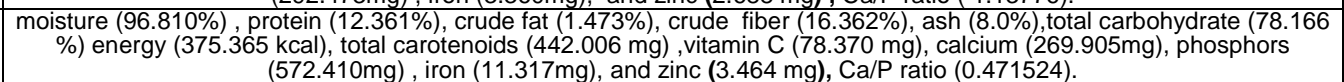 & $\begin{array}{l}\text { caloric deficiency, ,night blindness } \\
\text {,scurvy ,anemia, dwarfism. }\end{array}$ \\
\hline 3 & 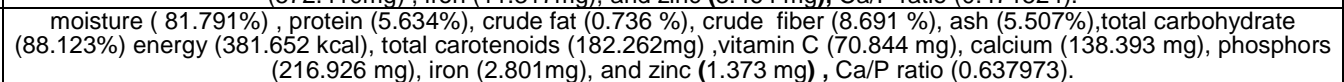 & $\begin{array}{c}\text { caloric deficiency, night blindness } \\
\text {, scurvy. }\end{array}$ \\
\hline 4 & 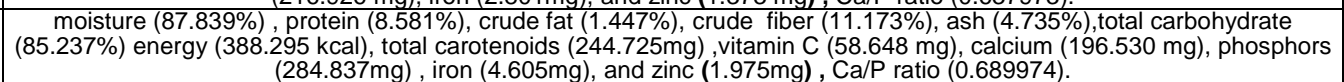 & $\begin{array}{c}\text { caloric deficiency, night blindness } \\
\text {,scurvy. }\end{array}$ \\
\hline 5 & 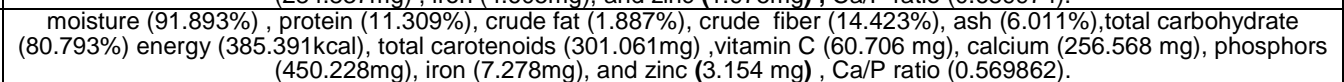 & $\begin{array}{c}\text { caloric deficiency, night blindness, } \\
\text { scurvy, anemia. }\end{array}$ \\
\hline 6 & 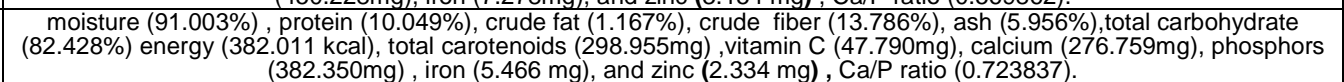 & $\begin{array}{c}\text { caloric deficiency, night blindness } \\
\text {, scurvy. }\end{array}$ \\
\hline 7 & 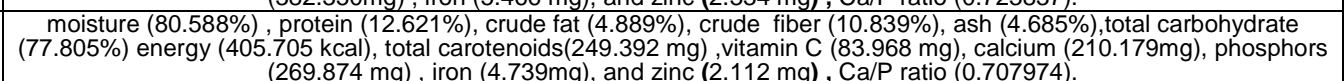 & $\begin{array}{c}\text { caloric deficiency, night blindness } \\
\text {, scurvy. }\end{array}$ \\
\hline 8 & 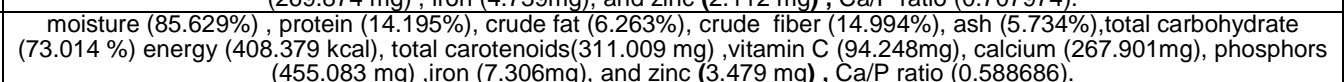 & $\begin{array}{l}\text { caloric deficiency , kwashiorkor, } \\
\text { night blindness , scurvy, anemia. }\end{array}$ \\
\hline 9 & 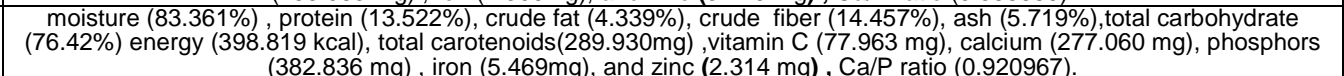 & $\begin{array}{c}\text { caloric deficiency, night blindness } \\
\text {, scurvy. }\end{array}$ \\
\hline 10 & 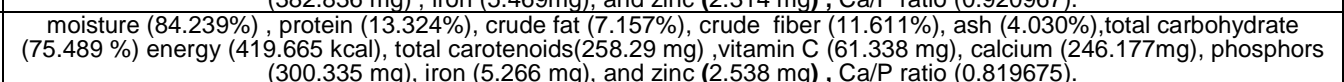 & $\begin{array}{c}\text { caloric deficiency, night blindness } \\
\text {, scurvy. }\end{array}$ \\
\hline 11 & 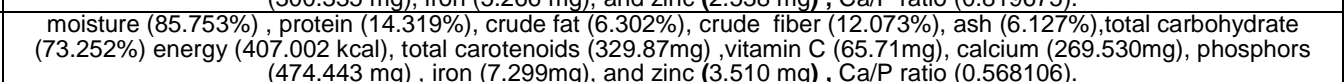 & $\begin{array}{l}\text { caloric deficiency, kwashiorkor } \\
\text { night blindness , scurvy, dwarfism, } \\
\text { anemia. }\end{array}$ \\
\hline 12 & 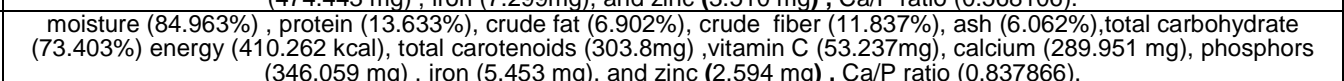 & $\begin{array}{c}\text { caloric deficiency, night blindness } \\
\text {, scurvy. }\end{array}$ \\
\hline 13 contr & 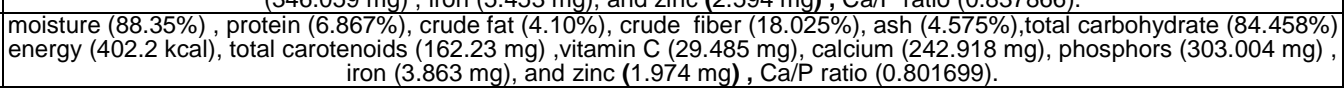 & caloric deficiency \\
\hline
\end{tabular}

